\title{
Mark Bowden, Hue 1968. Wietnam we krwi, tłum. Mateusz Fafiński, Poznań 2019, ss. 639
}

\author{
(c) $($ ) $\Theta$ \\ http://dx.doi.org/10.12775/KLIO.2020.012
}

$\mathrm{B}$ itwa o Hue, stoczona od końca stycznia do początków marca 1968 r., była najbardziej zaciętym i najkrwawszym starciem słynnej komunistycznej Ofensywy Tet w Wietnamie Południowym. Nic zatem dziwnego, że temat ten został przeanalizowany również w polskiej historiografii, m.in. w tekstach autora prezentowanej recenzji ${ }^{1}$ czy w monografii autorstwa Patryka Masnego ${ }^{2}$. Wątki z nim związane występowały także - jako element większej całości - w książce Jaremy Słowiaka ${ }^{3}$ poświęconej oblężeniu Khe Sanh, czyli innej niezwykle ważnej bitwie, ściśle połączonej z Ofensywą Tet.

W ostatnim czasie do książek i artykułów przygotowanych przez polskich znawców problematyki dołączyły, tłumaczone z języka angielskiego, dzieła cenionych zachodnich publicystów. Pierwszym z nich były dosyć już leciwe Depesze Michaela Herra ${ }^{4}$ (oryginał wydano w 1977 r.), w których

1 P. Benken, Ofensywa Tet 1968, Warszawa 2010; idem, Bitwa o Hue - najbardziej zacięte starcie Ofensywy Tet, w: Studia nad wojnami w Indochinach, t. 1, red. P. Benken, Oświęcim 2013; idem, Ofensywa Tet 1968. Studium militarno-polityczne, Szczecin 2014.

2 P. Masny, Bitwa o Hue 31 I-24 II 1968, Zabrze-Tarnowskie Góry 2016; zob. też: P. Benken, O bitwie o Hue z 1968 r. na kanwie najnowszej książki Patryka Masnego, „Przegląd Historyczno-Wojskowy” 2016, R. 18 (68), nr 4 (258).

3 J. Słowiak, Khe Sanh 1968. Amerykańskie i wietnamskie poszukiwania rozstrzygajacej bitwy, Zabrze-Tarnowskie Góry 2017.

4 M. Herr, Depesze, Kraków 2016. Warto dodać, że Michael Herr pracował przy scenariuszach filmów Czas apokalipsy i Full Metal Jacket. Duża część akcji tej ostatniej produkcji rozgrywała się w trakcie bitwy o Hue i wiele dialogów, a nawet całe sceny, nawiązywały wprost do epizodów przedstawionych w Depeszach. 
autor opisał swe jednostronne doświadczenia z pracy jako korespondent wojenny w Wietnamie w latach 1967-1969, dużo uwagi poświęcając walkom o Hue. Drugą pozycją, oryginalnie wydaną w 2017 r., było Hue 1968 Marka Bowdena (Wydawnictwo Poznańskie dodało do polskiej edycji podtytuł Wietnam we krwi). To właśnie ostatnia ze wspomnianych publikacji, która ukazała się w Polsce w 2019 r., jest przedmiotem tej recenzji.

Bowdena nie trzeba polskiemu czytelnikowi przedstawiać. Jest on znany nad Wisłą m.in. z doskonałej analizy głośnego nieudanego amerykańskiego rajdu na Mogadiszu z początku października 1993 r. pt. Helikopter $w$ ogniu ${ }^{5}$ wydanej w Polsce w 2011 r. Chociaż nie jest profesjonalnym historykiem, Bowden w swej monografii bitwy o Hue wykorzystał - prócz literatury przedmiotu - dostępne mu materiały źródłowe, podejmując nawet próbę wykonania ( $\mathrm{z}$ wykorzystaniem pośrednika) kwerendy w archiwach Socjalistycznej Republiki Wietnamu. Podstawą jego narracji stały się jednak liczne wywiady, jakie przeprowadził z uczestnikami opisywanych przez siebie wydarzeń. Przede wszystkim byli to weterani amerykańskiej piechoty morskiej, którzy walczyli w Hue, lecz nie zabrakło też relacji dawnych członków Narodowego Frontu Wyzwolenia Wietnamu Południowego i żołnierzy Wietnamskiej Armii Ludowej, mieszkańców miasta oraz weteranów Armii Republiki Wietnamu. Ci ostatni byli niestety reprezentowani w najmniejszym stopniu. Praca Bowdena potencjalnie nie tylko spełnia więc warunki do tego, by stać się podstawowym, przystępnym dla laika, kompendium wiedzy na temat tytułowego starcia, lecz również daje nadzieje na poszerzenie istniejącej dotąd wiedzy na temat bitwy o wiele interesujących szczegółów.

Książka Bowdena dzieli się na sześć części, epilog, postscriptum, podziękowania, sekcję z przypisami (w książce przyjęto niestety system oksfordzki) oraz indeks. Wadą tej konstrukcji jest brak bibliografii zmuszający do zapoznawania się z poszczególnymi odsyłaczami w celu poszukiwania konkretnych publikacji i materiałów źródłowych wykorzystanych przez autora.

Część pierwsza, złożona z 11 rozdziałów, przedstawia szerokie tło historyczne i bezpośrednią genezę nie tylko bitwy o Hue, lecz również Ofensywy Tet, słusznie identyfikując tytułowe starcie jako jeden z najważniejszych

5 M. Bowden, Helikopter w ogniu, Warszawa 2011. 
elementów większej operacji. Część druga, złożona z 5 rozdziałów, opisuje pierwszą fazę walki, gdy komunistom udało się opanować większość miasta, w tym kilka obiektów o dużym znaczeniu. Nie zdołali jednak całkowicie wyprzeć Amerykanów i żołnierzy ARW z Hue, dzięki czemu sojusznicy mogli rozpocząć pierwsze kontrataki. Reakcje dowódców amerykańskich i południowowietnamskich na uderzenie na miasto opisano w części trzeciej, złożonej z 6 rozdziałów, a także części czwartej, złożonej z 9 rozdziałów. Znalazły się tam informacje nie tylko o przebiegu walk w Hue, lecz także o operacjach prowadzonych poza nim, mających istotne znaczenie dla rezultatów bojów o miasto. Nie zaniedbano przy tym nakreślenia sytuacji komunistów, z jednej strony dążących do zaprowadzenia w zdobytej części Hue swych rządów (często z wykorzystaniem terroru), z drugiej zaś przygotowujących się na nieuchronne kontruderzenie. Część piątą, złożoną z 10 rozdziałów, poświęcono na bardzo szczegółowy opis działań oczyszczających prowadzonych przez amerykańską piechotę morską w Nowym Mieście (część Hue leżąca na północnym brzegu Rzeki Perfumowej). W części szóstej, złożonej z 13 rozdziałów, analizie poddano walki toczone przez Amerykanów na Starym Mieście (Cytadeli), którzy po pokonaniu komunistów w swojej strefie działań (Nowe Miasto) przeszli na drugi brzeg Rzeki Perfumowej, by wesprzeć niedostatecznie uzbrojone i liczne oddziały ARW w ciężkich bojach o opanowanie silnie ufortyfikowanych obiektów starówki. W epilogu i postscriptum autor przedstawił dalsze losy osób opisanych w książce, ujawnił swój osobisty stosunek do przedstawianych zagadnień oraz dokonał krótkiego omówienia wykorzystanych źródeł i literatury.

Przechodząc do oceny książki, należałoby zacząć od tego, że jeśli chodzi o ogólny przebieg działań bojowych, a nawet wiele szczegółów, polski czytelnik, który zapoznał się z treścią publikacji rodzimych badaczy wymienionych na początku recenzji, nie dowie się wiele nowego. Wynika to z tego, że Bowden nie sięgał do innych opracowań aniżeli wspomniani wyżej historycy ${ }^{6}$. Ogromnym atutem Hue 1968 są natomiast umiejętnie

6 Zob. m.in. E. Hammel, Fire in the streets: the battle for Hue, Tet 1968, Pacifica 1991; K. Nolan, Battle for Hue. Tet 1968, Novato 1984; J. Shulimson, L. Blasiol, Ch. Smith, D. Dawson, U.S. Marines in Vietnam. The defining year 1968, Washington 1997; G. Smith, The siege at Hue, London 1999. 
wykorzystane relacje amerykańskich żołnierzy z bojów o miasto. Umożliwiają one dokonanie wyczerpującej analizy walk ulicznych nie tylko na poziomie pułku, batalionu czy kompanii, jak to najczęściej bywa w publikacjach poświęconych bitwie, lecz również z perspektywy plutonu, drużyny, a nawet pojedynczych żołnierzy. Informacje owe niewątpliwie pozwoliły na uszczegółowienie wielu znanych epizodów oraz przedstawienie nowych.

Dla recenzenta ciekawostką był wątek ewakuacji z Hue 8 lutego członków zespołu Międzynarodowej Komisji Nadzoru i Kontroli w Indochinach, który znał on dotąd jedynie z raportu polskiego uczestnika tych wydarzeń:

Od chwili odbicia z brzegu aż do przybycia do rzeki Perfumowej barka, na której znajdowaliśmy się, była pod nieprzerwanym ogniem moździerzy, rakiet i broni maszynowej sił NFW. [...] Aż dziw bierze, że nie trafiła [w nią] żadna mina moździerzowa lub rakieta. Jednak w czasie przejazdu rzeką zostało rannych pięciu amerykańskich żołnierzy z ochrony barki ${ }^{7}$.

W książce Bowdena (s. 392-393) zdarzenie to opisano niemal identycznie, dodając jednak na koniec nieoczekiwaną puentę, której zabrakło w polskim raporcie:

Delegacja $[\mathrm{MKNiK}]$ została odnaleziona przez Marines poprzedniego dnia - ukrywali się w swojej kwaterze od tygodnia. [...] Żaden z pasażerów nie odetchnął, dopóki łódź nie odbiła i nie zaczął płynąć w dół rzeki. Ich ulga była jednak przedwczesna. Wkrótce z obu stron rzeki wybuchła kanonada. Widzieli żołnierzy wroga strzelających do nich z granatników przeciwpancernych. [...] Gdy wpłynęli w boczny kanał strzały stały się bardziej intensywne. Mała łódź patrolowa za nimi została trafiona rakietą i zatonęła. Czerwone pociski smugowe przelatywały im nad głowami, a ranni Marines próbowali odpowiadać ogniem. [...] Jeden z Kanadyjczyków, major, wyciągnął zza pazuch butelkę szkockiej. [...] Kiedy dotarli do Morza Południowochińskiego łódź zaczęła się kołysać na falach. Jeden z Polaków podszedł [...] i poprosił Kanadyjczyka w łamanym angielskim, czy ma ze sobą dramaminę (pigułki na chorobę lokomocyjna).

7 Cyt. za: P. Benken, Ofensywa Tet 1968. Studium..., s. 153. 
- Widziałem je dzisiaj rano w twoim biurze - powiedział.

- Boże, w całym tym pośpiechu zapomniałem ich ze sobą zabrać - odparł major.

Polak pokuśtykał na drugą stronę, wychylił głowę za burtę i zwymiotował. Wtedy major wyjął buteleczkę tabletek z jednej ze swoich licznych kieszeni. Podrzucił ją w dłoni:

- Pieprzyć go - powiedział w stronę Polaka. - On pracuje dla drugiej strony.

Należałoby podkreślić, że na wysoką ocenę publikacji zasługuje poświęcenie przez autora dużej ilości miejsca kwestiom związanym z taktyką amerykańskiej piechoty morskiej i jej współpracy z bronią pancerną (m.in. czołgi, samobieżne niszczyciele czołgów). Solidnie omówiono również aspekty dotyczące łączności, wsparcia artyleryjskiego i lotniczego, jak również pracy wywiadowczej, trafnie identyfikując najistotniejsze błędy i zaniedbania. Cenne były też przemyślenia odnoszące się do wpływu ciężkich, przewlekłych i okresowo niepomyślnych walk w mieście na morale biorących w nich udział żołnierzy amerykańskich.

W pracy Bowdena zawarto także, m.in. na podstawie przeprowadzonych wywiadów, informacje o stronie komunistycznej (liczebność, organizacja, taktyka, uzbrojenie). Fragmenty te były interesujące i pod pewnymi względami rozszerzyły dotychczasową wiedzę na temat tytułowego starcia.

Bowdena należałoby bezdyskusyjnie pochwalić za to, że relatywnie wiele miejsca poświęcił na ukazanie tragicznych losów mieszkańców Hue, którzy nieoczekiwanie dla siebie znaleźli się na linii frontu jednej z najbardziej zaciętych bitew miejskich, jakie stoczono po 1945 r. Było to ważne z tego względu, że w licznych publikacjach, poświęconych głównie aspektom militarnym, wątek ten był marginalizowany i często ograniczał się do kilku akapitów na temat komunistycznych zbrodni na cywilach i ogólnego podsumowania strat poniesionych przez mieszkańców Hue w trakcie walk. Bowden ukazał konkretne tragedie, dotykające często całe rodziny i zmuszające do niezwykle trudnych wyborów decydujących o życiu lub śmierci. Co godne odnotowania, autor opisał bardzo różnorodne spektrum postaw przyjmowanych przez ludność cywilną.

Duży niedosyt recenzenta wzbudził natomiast sposób przedstawienia przez Bowdena żołnierzy Południa, którzy - chociaż w tytułowej bitwie 
odegrali dużą rolę - najczęściej pełnili w jego narracji funkcję statystów. Wyjątkiem było m.in. powtórzenie dobrze już opisanych w literaturze przeżyć dowódcy południowowietnamskiej kompanii rozpoznawczej („Czarne Pantery”) należącej do 1. Dywizji Piechoty, która przyjęła na siebie pierwsze uderzenie wroga w Cytadeli. Żołnierzy i oficerów ARW próżno było szukać w większej liczbie na liście osób, z którymi autor przeprowadzał rozmowy podczas pracy nad książką, a i z tych wywiadów, które doszły do skutku (m.in. ze wspomnianym dowódcą „Czarnych Panter”), nie wydobyto właściwie żadnych nowych treści. Jest to poważne zaniedbanie, tym bardziej że istnieją publikacje autorów południowowietnamskich pozwalające na o wiele bardziej szczegółowy opis działań w Hue z ich perspektywy ${ }^{8}$, nie wspominając już nawet o znanej książce Andy’ego Wiesta poświęconej wojskowości Południa ${ }^{9}$, której próżno szukać w przypisach Bowdena.

Chociaż recenzowana publikacja nie jest pracą naukową, to jednak przez podkreślanie przez jej autora wykorzystania najważniejszej literatury przedmiotu i źródeł (dokumentów i relacji), jak również opatrzenia jej aparatem naukowym w postaci przypisów, może być tak właśnie odbierana. Z ową kwestią wiążą się, zdaniem recenzenta, najważniejsze jej mankamenty, czyli jednostronne oceny Bowdena wynikające z jego osobistych opinii na temat konfliktu w Indochinach oraz $\mathrm{z}$ niedostatecznego przygotowania do podejmowania się całościowego opracowania skomplikowanych wydarzeń rozgrywających się nie tylko w Hue, lecz również w całym Wietnamie Południowym, a także Waszyngtonie. Autor nie ograniczył się bowiem do analizy walk o miasto, lecz przedstawił tytułową bitwę jako punkt zwrotny wojny, podejmując się wielopłaszyznowej oceny wytworzonej przez nią sytuacji.

Wspomniany wyżej problem jednostronnych ocen można było zaobserwować m.in. w widocznym relatywizowaniu przez Bowdena skali komunistycznych zbrodni w trakcie okupacji miasta. Komuniści, wkraczając do Hue, mieli już przygotowane listy osób przeznaczonych do likwidacji. Znajdowali się na nich m.in. żołnierze, policjanci i urzędnicy państwowi,

8 Hoang Ngoc Lung, The General Offensives of 1968-69, Mc Lean 1981; Pham Van Son, The Viet Cong 'Tet' Offensive, Christiansburg 1968.

9 A. Wiest, Vietnam's forgotten army, New York 2008. 
których mordowano wraz z całymi rodzinami. Zdarzało się także, że ginęli ludzie, którzy nie poparli NFW. Bowden starał się zaniżyć skalę czystek, uznając za zawyżoną liczbę 2800 ofiar komunistów podaną przez Douglasa Pike'a. Porównał je przy tym ze stratami ludności cywilnej w toku walk ulicznych i późniejszej akcji odwetowej przeprowadzonej przez władze Południa (s. 539-540):

Front w ramach czystek zamordował od trzystu do nawet czterech tysięcy ośmiuset pięćdziesięciu sześciu osób. Tak absurdalny rozstrzał w liczbie ofiar wynika z tego, kto je podaje. [...] Nigdy się nie dowiemy ilu dokładnie rozstrzelano, lecz nie ma wątpliwości, że Front regularnie likwidował tych, którzy byli w jakiś sposób związani z reżymem w Sajgonie, podobnie zresztą jak czynił to ów reżym po zakończeniu bitwy - liczby ofiar tej czystki także nie znamy. Ostrożne obliczenia mówią o dwóch tysiącach ${ }^{10}$.

Charakterystyczny stosunek Bowdena do liczby ofiar wśród ludności cywilnej powrócił także przy ocenie mocno krytykowanego dowódcy wojsk amerykańskich w Wietnamie, gen. Williama Westmorelanda (s. 568):

Żałował zniszczenia historycznego miasta i de facto oskarżył Hanoi o śmierć cywilów w mieście, wspominając tylko o tych, którzy zginęli

$10 \mathrm{~W}$ jednym z przechwyconych dokumentów zdobywcy Hue pisali o likwidacji 1800 urzędników, 38 policjantów i 790 innych „tyranów” (zob. P. Benken, Ofensywa Tet 1968. Studium..., s. 157). Gdyby przyjąć wyliczenia autora, tj. do podanych przez niego szacunków ofiar akcji odwetowej Sajgonu dodać cywili zabitych podczas nalotów i ostrzału (aczkolwiek jak ocenić, ilu spośród tych cywili zginęło od przypadkowych lub celowo wystrzelonych kul komunistów?), okaże się, że Amerykanie i Wietnamczycy z Południa być może „wymordowali” nawet więcej mieszkańców miasta niż siły NFW/WAL. Warto także zwrócić w tym kontekście uwagę na to, że w notatce informacyjnej, przesłanej przez Attachat Wojskowy przy Ambasadzie Polskiej Rzeczypospolitej Ludowej w Hanoi w maju 1968 r., stwierdzano: „Siły Frontu Wyzwolenia Narodowego i ludność wykonują wyroki na tych przedstawicielach władzy, którzy się wyróżnili swym okrucieństwem wobec ludności” (Archiwum Instytutu Pamięci Narodowej w Warszawie [dalej: AIPN], 2602/7976, Notatka informacyjna dotycząca działań bojowych na terytorium Wietnamu Południowego w okresie 1-10 V 1968 r., 15 V 1968, k. 351). Wydaje się, że tego rodzaju propagandowe wytłumaczenie brutalnych działań jest w pewnym stopniu przejmowane przez autora recenzowanej publikacji. 
w czystkach. Zupełnie pominął cywilów zabitych w czasie amerykańskich i południowowietnamskich bombardowań.

Komentując ten fragment, recenzent uznał, że Bowden z kolei zupełnie pominął ważki fakt, że cywile nie byliby zabijani, gdyby komuniści nie zaatakowali w okresie tradycyjnego zawieszenia broni miasta, w którym nie przebywały większe siły wojskowe, by wykorzystać Hue i jego ludność do swoich celów. Niekombatanci tracili życie głównie z dwóch powodów: 1) na skutek komunistycznych czystek, 2) ponieważ konieczność odbijania poszczególnych zabudowań, które przekształcono w ufortyfikowane stanowiska obronne, z cywilami odgrywającymi rolę zakładników (nie pozwalano im opuszczać obszarów opanowanych przez NFW i WAL) wymusiła wprowadzenie do akcji broni pancernej, a następnie - artylerii i lotnictwa.

Śmierć niewinnych ludzi zawsze musi być tragedią, niemniej należałoby pamiętać, kto doprowadził do nieszczęścia i kto, jak pisał autor, świadomie je przedłużał, upatrując w przeciąganiu się walki o Hue możliwość uzyskania sukcesu propagandowego, nawet wtedy, gdy stało się jasne, że pod względem militarnym komuniści nie będą w stanie wygrać.

Trudno jednoznacznie ocenić, czemu miało służyć podejście Bowdena, który starał się przedstawić straty ludności cywilnej ponoszone w trakcie odbijania miasta przez siły amerykańskie i południowowietnamskie jako cięższe oraz wiążące się dla mieszkańców Hue z większą traumą aniżeli rozstrzeliwanie członków ich rodzin przez komunistów (s. 570):

\footnotetext{
Najwięcej spośród zabitych zginęło przez przypadek, od zagubionej kuli lub w wyniku ostrzału artyleryjskiego. [...] Ci [cywile], którzy przeżyli bitwę, bez wahania opisywali bombardowania jako najstraszniejsze wspomnienie, nawet jeśli członkowie ich rodzin zginęli także w czystkach. Hanoi może i nie przysporzyło sobie zwolenników po zajęciu Hue, lecz i sprzymierzeni nie zyskali poklasku odbijając miasto.
}

Zadziwiające, zdaniem recenzenta, było dążenie Bowdena do przedstawiania rezultatów bitwy jako ograniczonego sukcesu komunistów ze względu na pozytywne dla Hanoi skutki propagandowe przedłużających się walk w mieście. Alternatywą było dla niego uznanie, że „obie strony przegrały” bitwę o Hue (s. 569). Jest to w ocenie recenzenta nieporozumienie, gdyż 
pod względem militarnym należałoby mówić o drogo wprawdzie okupionym, ale jednak sukcesie strony amerykańsko-południowowietnamskiej. Również w aspekcie polityczno-propagandowym sprawy nie wyglądały tak jednoznacznie, jak chciałby to widzieć autor. Komunistom nie udało się osiągnąć niemal żadnego z planowanych głównych celów ofensywy, do których zaliczano: wywołanie tzw. powstania ludowego o powszechnym charakterze, osłabienie rządu w Sajgonie i jego armii oraz oddziaływanie na amerykańską opinię publiczną, by doprowadzić do wycofania się Stanów Zjednoczonych z Indochin. Pewien sukces, który jednak nie przesądzał jeszcze o końcowym rezultacie konfliktu (jak się to często przedstawia), udało się osiągnąć jedynie w ostatnim aspekcie, aczkolwiek za cenę ogromnych strat. Późniejsze twierdzenia weteranów NFW, cytowanych przez Bowdena, jakoby od początku zamierzali oni jedynie jak najdłużej utrzymywać się w opanowanym mieście, by wpływać na opinię publiczną w Ameryce, są mało wiarygodne, a ponadto nie znajdują potwierdzenia w wielu źródłach, w tym również komunistycznej proweniencji, przedstawiających Ofensywę Tet jako w znacznym stopniu rozczarowanie ${ }^{11}$. Hue, jako dawna stolica cesarska, a więc miejsce o wielkim znaczeniu symbolicznym, a przy tym jedno z trzech największych miast Południa, leżące blisko strefy zdemilitaryzowanej i mające opinię „antyrządowego”, było ważnym elementem komunistycznych planów wywołania „powstania ludowego”, do którego nie doszło. Ludność Południa poparła NFW w stopniu o wiele mniejszym, aniżeli przewidywano.

Inną kwestią, na którą warto byłoby zwrócić uwagę, okazało się przekonanie autora książki, w ocenie recenzenta niesłuszne, o rzetelności ówczesnej prasy amerykańskiej w kontekście relacjonowania przebiegu wydarzeń w Indochinach. Analiza związana z medialnym aspektem bitwy o Hue i całej Ofensywy Tet zajmowała w książce Bowdena niemało miejsca, jednak trudno nie odnieść wrażenia, że zaprezentowane przez niego wnioski nie wychodziły poza schematy, które utrwaliły się jeszcze na przełomie lat 60. i 70. (s. 570):

11 P. Benken, Ofensywa Tet 1968 w dokumentach Attachatu Wojskowego przy Ambasadzie PRL w Hanoi w latach 1968-1969, w: Studia nad wojnami w Indochinach, s. 72-77. 
Wielu winiło dziennikarzy za przegraną w wojnie, lecz amerykańskie doniesienia prasowe i telewizyjne $\mathrm{z}$ Wietnamu były znacznie bardziej dokładne i bliższe prawdy, niż oficjalne oświadczenia władz; były też pełne sympatii i szacunku dla walczących tam Amerykanów. Reporterzy w Hue słuchali, obserwowali, opisywali i fotografowali, ryzykując bardzo wiele.

Oczywiście, przyczyny amerykańskiego niepowodzenia w Indochinach były złożone i z pewnością nie można ich ograniczyć li tylko do nierzetelnych materiałów informacyjnych, którymi karmiono opinię publiczną w Stanach Zjednoczonych. Niemniej nie można się też zgodzić ze stwierdzeniem, iż relacje z Wietnamu miały obiektywny charakter, gdyż nie wytrzymuje to konfrontacji ze źródłami, które obecnie są do dyspozycji badaczy $^{12}$. Obalają one także wiele mitów dotyczących zwłaszcza Demokratycznej Republiki Wietnamu i Republiki Wietnamu (Południa), jakie tworzono i utrwalano przez lata m.in. dzięki powszechnie cenionym i nagradzanym autorytetom Zachodniego dziennikarstwa, takim jak David Halberstam, Neil Sheehan czy Michael Herr. Trudno obecnie zaprzeczać, niezależnie od motywacji, które kierowały amerykańskimi publicystami, że wielu z nich, mając jawnie krytyczny stosunek do działań Stanów Zjednoczonych w Wietnamie i rządu w Sajgonie w szczególności, osłabiało rezultaty wysiłku wojennego swego kraju w Indochinach ${ }^{13}$.

Posługując się przestarzałymi schematami, Bowden prezentował także niezrozumienie kwestii związanych z sytuacją wewnętrzną RW, stwierdzając (s. 571-572):

12 Zob. np. P. Benken, Archiwum Instytutu Pamięci Narodowej jako narzędzie do badań wojen i konfliktów zbrojnych po 1945 r. na przyktadzie II wojny indochinskiej, w: Wojny i konflikty zbrojne po 1945 r. Zbiór studiów, t. 4, red. M. Giętkowski, Ł. Nadolski, Bydgoszcz 2017.

13 Zob. m.in. D. Schmitz, The Tet Offensive. Politics, war and public opinion, Lanham 2005. W jednej z notatek informacyjnych dotyczących oceny Ofensywy Tet, przesłanych przez Attachat Wojskowy przy Ambasadzie PRL w Hanoi, znalazła się informacja: „Dziennikarze zachodni porównywali zniszczenia w skutek bombardowań w mieście Can Tho do zniszczeń spowodowanych przez bombę atomową w Hiroszimie" (AIPN, 2602/7976, Notatka informacyjna dotycząca działań wojennych na terytorium Wietnamu w miesiącu styczniu 1968 r., 13 II 1968 r., k. 54). 
Sprowadzenie konfliktu na ulice miast znacznie podkopało wiarę zwykłych Wietnamczyków w rząd prezydenta Thieu. Pozbawionych ideologii obywateli - to znaczy większość obywateli - interesowało tylko przetrwanie. Chcieli być po stronie zwycięzców, gdy wojna dobiegnie końca. Ofensywa Tet obniżyła szanse na to, że Sajgon okaże się zwycięzcą. Hanoi może się i przeliczyło, lecz w dłuższej perspektywie ofensywa przyniosła pozytywne skutki, z którymi północnowietnamscy przywódcy w ogóle się nie liczyli.

Trudno byłoby zgodzić się $\mathrm{w}$ pełni $\mathrm{z}$ interpretacją przedstawioną w powyższym cytacie, biorąc pod uwagę, że na Południu po Ofensywie Tet zachodził wyraźnie zauważalny proces umacniania się struktur władzy sajgońskiej. Jedną z przyczyn było to, że działania wojenne z 1968 r. doprowadziły do wykrwawienia najlepszych oddziałów partyzanckich, a i zbrodnie komunistyczne zmniejszyły liczbę sympatyków „rewolucji”. Fakt ten jest także dostrzegalny w źródłach komunistycznej proweniencji ${ }^{14}$. Oczywiście sytuacja Sajgonu z różnych względów była daleka od idealnej, niemniej Hanoi także musiało zmagać się z potężnymi trudnościami wynikającymi z prowadzenia długiej i wyczerpującej wojny, które coraz mocniej dawały o sobie znać. Jedynie nieustająca pomoc ze strony „bratnich narodów” i utrzymywanie własnego społeczeństwa w żelaznej dyscyplinie sprawiły, że konflikt mógł być przez DRW kontynuowany i zdołała ona wytrwać do momentu, w którym zniechęcenie amerykańskiej opinii publicznej do dalszych działań w Indochinach mogło zwiastować zwycięstwo. Zwycięstwo, które kosztem dalszych olbrzymich strat i po wielu następnych poważnych niepowodzeniach (m.in. nieudana ofensywa z 1972 r.) osiagnięto dopiero w 1975 r.

Wydaje się, że odpowiedź na pytanie o przyczyny tak specyficznego rozłożenia przez autora niektórych akcentów w jego książce daje jego deklaracja zamieszczona na jednych z ostatnich jej stron (s. 572-573):

Z perspektywy niemal pięćdziesięciu lat bitwa o Hue i cała wojna w Wietnamie wydają się tragiczną i pozbawioną sensu pomyłką. Tyle bohaterstwa, tyle śmierci i cierpienia i wszystko to tylko dla sprawy, która

${ }_{14}$ Zob. P. Benken, Ofensywa Wielkanocna 1972. Kulminacyjny punkt wojny wietnamskiej, Oświęcim 2012, passim. 
teraz wydaje się bezsensowna i nieaktualna. [...] Według mnie [amerykańscy żołnierze] zostali cynicznie wykorzystani, ich idealizm i lojalność wyzyskana została przez przywódców, którzy sami stracili wiarę w prowadzenie wojny. Była to wielka zdrada, która pozostaje olbrzymią tragedią i hańbą.

Uznając prawo Bowdena do przedstawienia swej oceny, można jedynie ubolewać, że pojawiła się ona tak późno, bo dopiero w epilogu. W ocenie recenzenta czytelnik powinien być od początku poinformowany o tym, że autor ma do opisywanych przez siebie wydarzeń silnie skrystalizowany stosunek, który bez wątpienia wpłynął na sposób przedstawiania przez niego przynajmniej niektórych faktów i ocen. Nie do przyjęcia było już jednak to, że Bowden, prezentując swą niechęć wobec amerykańskiej polityki w Wietnamie, a szczególnie wobec jej głównego realizatora w osobie gen. Westmorelanda, nie próbował nawet ukazać odmiennego punktu widzenia na problem, który od wielu lat coraz mocniej wybrzmiewa $\mathrm{w}$ dyskusjach prowadzonych $\mathrm{w}$ amerykańskim środowisku naukowym. Wielu cenionych historyków spogląda obecnie na państwowość południowowietnamską z dużo większą życzliwością, widząc w niej coś więcej aniżeli tylko „amerykańską marionetkę”; bardziej wyważone stają się sądy na temat polityki amerykańskiej w Indochinach i koncepcji gen. Westmorelanda dotyczących prowadzenia konfliktu ${ }^{15}$.

Na koniec kilka uwag odnoszących się do kwestii warsztatowych.

Jak już wyżej wspomniano, Bowden podjął próbę pozyskania materiałów z archiwów SRW, jednak - nie znając języka wietnamskiego i nie mając dostępu do tych źródeł - skorzystał z informacji przekazanych przez współpracownika, „niezależnego tłumacza” i byłego oficera sił zbrojnych SRW, który „przejrzał” dla niego materiały Hanoi i podzielił się wiedzą, którą w ten sposób pozyskał. W ocenie recenzenta trudno mówić o tym, by taki sposób wykonania kwerendy mógł być uznany za rzetelny, nawet jeśli Bowden wszedł w posiadanie informacji robiących wrażenie autentycznych.

15 Zob. M. Moyar, Vietnam: historians at war, „US Army Research” 2008, no. 1; J. Słowiak, Konflikt, którego nie dato się wygrać? Niekończący się spór amerykańskiej historiografi o wojne w Wietnamie, w: Wojny i konflikty zbrojne po 1945..., s. 209-215. 
Charakterystyczne były również wywiady przeprowadzane przez autora z osobami żyjącymi wciąż w SRW. Podczas wielu z nich funkcję tłumacza pełnił zastępca dyrektora w Centrum Prasy Zagranicznej w Hanoi i nawet Bowden przyznawał: „[... ] jego obecność miała paraliżujący wpływ na moich rozmówców”. Autor książi zacytował również przetłumaczony po jego powrocie do Stanów Zjednoczonych fragment nagranej na taśmę rozmowy między weteranem NFW a "tlumaczem”, bezpośrednio poprzedzającej wywiad (s. 575):

- Mówię, by mógł pan przekazać komitetowi partyjnemu i komitetowi okręgowemu informacje o tym wywiadzie między moją osoba, a tym oto pisarzem [...]. Jestem członkiem komitetu powiatowego i dlatego muszę się upewnić, że przestrzegam procedur.

- Tak, dokładnie - odpowiedział Linh [tłumacz] - i dlatego tu jestem. Jeśli coś nie będzie w porządku, dam znać. Jestem odpowiedzialny za prasę i informację. Pracuję w Departamencie Spraw Zagranicznych. Panie Dong, proszę się nie martwić. Jeśli padnie coś wartego upomnienia, dam panu znać.

Cytat powyższy, podany w epilogu książki przez jej autora, bardzo dużo mówił o wiarygodności wspomnień m.in. weteranów NFW, z których obficie korzystano. Co ciekawe, także tym razem Bowden poinformował czytelnika o tym ważkim dla jego narracji fakcie dopiero na ostatnich stronach książki. Być może autor obawiał się, że jeśli uczyni to wcześniej, zaszkodzi to pełnej implementacji u potencjalnego czytelnika prezentowanych przez siebie wniosków?

Jak już wyżej częściowo zwracano na to uwagę, ciekawy był również dobór rozmówców i głębia poszczególnych wywiadów. Bowden stwierdzał wprost: „Wietnamscy weterani, z którymi rozmawiałem, dumnie prezentowali w swoich domach medale i mówili o bitwie, jako ciężkiej, lecz słusznej próbie” (s. 576). Tymczasem jeśli chodziło o Amerykanów, to „niemal wszyscy nosili w sobie gniew za zdradę ich młodzieńczego idealizmu w większości przez amerykańskich przywódców, którzy wysłali ich do walki w wojnie niemożliwej do wygrania od samego początku” (s. 577). Recenzent uważa za zasadne zadać pytanie: gdzie w tym wszystkim był autor i czy biernie poddawał się wpływowi swych rozmówców, czy też może mówili mu oni to, co chciał usłyszeć? 
Podsumowując, należałoby stwierdzić, że recenzowana publikacja jest z pewnością książką ważną, a jej autor poświęcił dużo wysiłku na jej przygotowanie. Napisana jest bardzo dobrym językiem; trzeba też pochwalić polskiego tłumacza, który - wyjąwszy kilka drobnych potknięć, o których nie warto nawet szerzej wspominać - sumiennie wykonał swoją pracę. Hue 1968 jest niewątpliwie kopalnią wiedzy na temat taktycznych aspektów walk w mieście, do jakich doszło w dawnej cesarskiej stolicy. Można ją też uznać za najpełniejszą obecnie monografię tej bitwy dostępną w języku polskim, aczkolwiek silne zaznaczone poglądy autora na temat konfliktu powodują, że książkę należy czytać razem z innymi pracami poświęconymi tej problematyce. W tym momencie można wyrazić ubolewanie, że Wydawnictwo Poznańskie nie pokusiło się o przygotowanie wstępu do wydania polskiego, w którym można by, jak zrobiono to chociażby w tej recenzji, przedstawić wskazówki i uzupełnienia dla czytelnika. Z uwagi na to, że książka jest tego elementu pozbawiona, jej oddziaływanie na czytelnika w pewnych aspektach może być niekorzystne, gdyż znane nazwisko autora i to, że publikacja ukazała się relatywnie niedawno, wzbudzi zapewne duże zaufanie do zawartych w niej treści, na które nie w pełni zasługuje.

\author{
Przemystaw Benken (Szczecin) \\ Nr ORCID 0000-0002-1385-3016
}

